\title{
Contents Vol. 35,1973
}

\section{Confinia Neurologica}

Borderlands of Neurology

Official Organ of the International Society for Research in Stereoencephalotomy

Editor:

Associate Editor: Editorial Board: 
E. A. Spiegel, Philadelphia, Ph. L. Gtldenberg, Tucson,

L. AUBXANDER,

Boston, Mass.

A. AUSTREGESTLO,

Rio de Janeiro

A. BARRE, Strasbourg

G. BODECHTEL, München

L. VAN BOGAERT, Anvers

T. BROMAN, Göteborg

H. CAIRNS, London

P. COKKALIS, ATHEN

P. DeLMAS-MARSALET,

Bordeaux

S. FELDMAN, Jerusalem

J. F. FOLKERTS, Amsterdam

A. Hautant, Paris

G. HOLMES, London

B. HORANYI, Budapest 
Pa. Ariz.

L. VAN DER Horst, Amsterdam J. Igersheimer, New York, N.Y. W. KLESTADT, New York, N.Y.

A. KnAPP, New York, N. Y. H. KÜHLEnBeCK, Philadelphia, Pa. F. LeIRI, Helsinki R. Lorente De Nó, New

York, N.Y. E. LuDWIG, Basel

A. MONTANDON, Genève

H. NARABAYASHI, Tokyo

B. S. NASHOLD, Jr.,

Durham, N.C. 
F. NAVTLLE, Genève

C. NYLÉN, Uppsala

S. OBRADOR, Madrid

J. OLNTNCK, New York, N.Y.

K. ORZECHOWSKI, Warszawa

T. J. PUTNAM,

Los Angeles, Calif.

T. RTECHERT, Freiburg i. Br.

L. RÜEDI, Zürich

A. SCHÜLER, Melbourne

E. B. STREIFF, Lausanne

J. TALATRACH, Paris

M. Velasco-SuareZ,

Mexico

P. H. WTLCOX,

Traverse City, Mich.

E. WTLDI, Genève 


\section{Contents}

BssmanN, W. B.: Neuromolecular Modulation of Experimentally-Induced Retro grade Amnesia

VUIA, O.: Hypoplasia of the Circle of Willis Associated with Cerebrocerebellar Vascular Micromalformations in a Child (lts Relationsh ip to Nishimoto-

Kudo's Disease). Anatomoclinical Study

FELDMAN, S. andHAYAT, A.: Electrophysiological Studies of Somatosensory ProjectionstotheSeptumoftheCat.

REMLER, M.P.: Focal Stimulation of the Brain by Entirely Extracranial Means. AnExample of Ra\&ationControlled Focal Pharmacology....

COloff, E.; Gleason, C. A.; AlberTs, W.W., and WriQht, E.W., jr.: ComputerAided Localization Techniques for Stereotaxic Surgery

AlBERTS, W.W.; WrIGHT, E.W.,jr., and FBiNSTErN, B.: An Integrated System for Brain Stimulation and Lesion Production in Human Stereotaxic Surgery 81 Herishanu, Y.: On a Lower Brain Stem Localization of the Center of Periodic Blinking

NASHOLD,B.S., jr.; FlANIGIN, H., jr.; Wilson, W.P., and STEWART, B.: Stereotactic Evaluation of Bi temporal Epilepsy with/Electrodes and Lesions . 94

LARSON, S. J. and SANCES, A., jr.: CorticalProjections of Nucleus ventralis lateralis in Man

TASKer, R.R. and Organ, L.W.: Percutaneous Cordotomy Physiological Identi fication of Target Site

Wycis, T.; IwaTA, Y.; Bross, R.; COOK, K., and ROHRBACK, D.: A New Universal Stereoencephalotome (Model 6).

Zervas, N.T.; Shtntani, A.; Kuwayama, A.; Halb, R.; Pickrbn, K., and MbrRY, A.: Experimental Induction Heating Hypophysectomy

BALASUBRAMANIAM, V.JKANAKA, T.S.; RAMANUJAM, P.B., and RAMAMURTHI, B.: Stereotaxic Hypothalamotomy ....

ShaPiro, D.Y.; SADOWSKY, D.A.; Henderson, W.G., and VAn Buren, J. M.:

An Assessment of Cognitive Function in Fostthalamotomy Parkinson

Patients

SROKA, H.; Solsi, P., and BornsteIn, B.: Alexia without Agraphia with Complete Recovery. Functional Disconnection Syndrome

KotT, E.; Golan, A.; Don, R., and Bornstein, B.: Muscular Dystrophy: The Relative Frequency in the Different Ethnic Groups in Israël

KLAWANS, H.L., jr. and Ringel, S.P.: L-Dopa, Be, and a-Methyldopa Hydrazine WolPOw, E.R.: Focal Rhythmic EEG Slowing with Temporal Lobe Tumors. Re port of Six Cases

VAn Buren, J. M.; Li, ChOH-LUH; SHAPIRO, D. Y.; HeNDERSON, W. G., and SADOW SKY, DORIS A.: A Qualitative and Quantitative Evaluation of Parkinsonians Three to Six Years Following Thalamotomy 
Bekény, G. and Peter, Agnes: Meningocerebral Cysticercosis with Auditory Perseveration (Palinacusis)

SteINER, J.B.; GADOTH, N., and MoSES, S. W.: The Influence of Topically Applied 2)-Tubocurarine on the Taste-Induced Electrical Nerve Activity in the

Frog...

TOMASCH, J.: Cell Frequencies in the Abducens Nucleus of Man.

Broggi, G.; CARACENI, T., and Negri, S.: An Analysis of a Trigemino-Facial

Reflex in Normal Humans.

GaINOTTT, G. and TiaCCI, C.: The Unilateral Forms of Finger Agnosia. An BxperimentalStudy

GIAQUINTO, S.: Sleep Recordings from Limbic Structures in Man

Maneus, J.; Reichenthal, E.; Merzbach, D.; Haschman, N., and Peyser, E.:

Cryptococcus neoformans Meningitis. Report of a Case and Review of

Cryptococcosis in Israël.

FAnN, W.E.; Gerber, C. J., and McKBnZIE, G. M.: Physostigmine in Rigid Huntington's Disease.

HENDERSON, W.G.; SADOWSKY, D.A.; SHAPIRO, D.Y., and VAN BUREN, J.M.:

Quantitative Testing and its Usefulness in the Evaluation of Therapy in

Neurological Diseases

WILSON, W.P. and NASHOLD, B.S.: Evoked Photic Responses from the Human

Thalamus and Midbrain

NisheDA, T. andZiEGLER, D.K.: Acute Necrotic Myelopathy in Association with Lymphoma Cells of the Reticulo-Endothelial System, Acute Torticollis

and Recurrent Cardiac Arrest.....

ZoRuB, D. S. and RichARDSON, D.E.: An Extralemniscal Projection to the Centrum medianum and Pulvinar of the Thalamus

Klawans, H.L., jr.; Bergen, D., and Bruyn, G. W.: Prolonged Drug-Induced Parkinsonism

$123,316,378$

Book Reviews

News

Author Index

381

Subjectindex 